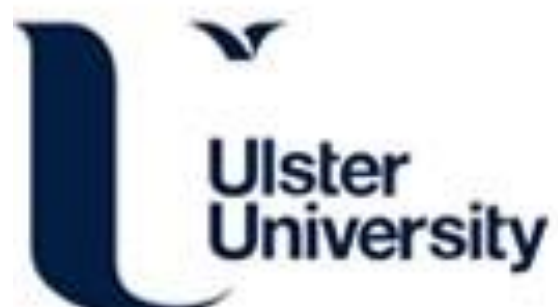

\section{Thinking outside the square: Creating value and emotion in ceramic tiles through design-led innovation}

Coulter, J., \& McKeag, D. (2013). Thinking outside the square: Creating value and emotion in ceramic tiles through design-led innovation. Design Principles and Practices: An International Journal of Designed Objects, 6(1), 31-42. http://designprinciplesandpractices.com/

Link to publication record in Ulster University Research Portal

\section{Published in:}

Design Principles and Practices: An International Journal of Designed Objects

Publication Status:

Published (in print/issue): 13/03/2013

\section{Document Version}

Publisher's PDF, also known as Version of record

\section{General rights}

Copyright for the publications made accessible via Ulster University's Research Portal is retained by the author(s) and / or other copyright owners and it is a condition of accessing these publications that users recognise and abide by the legal requirements associated with these rights.

\section{Take down policy}

The Research Portal is Ulster University's institutional repository that provides access to Ulster's research outputs. Every effort has been made to ensure that content in the Research Portal does not infringe any person's rights, or applicable UK laws. If you discover content in the Research Portal that you believe breaches copyright or violates any law, please contact pure-support@ulster.ac.uk. 
The International Journal of

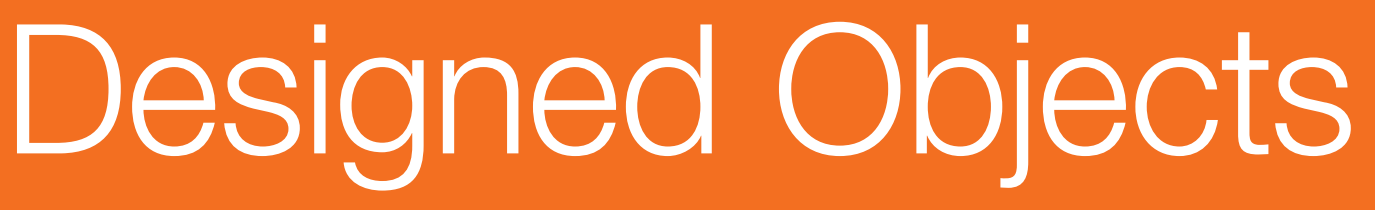

\section{Thinking Outside the Square}

Creating Value and Emotion in Ceramic Tiles through Design Led Innovation

JANET COULTER AND DENNIS MCKEAG 
THE INTERNATIONAL JOURNAL OF DESIGNED OBJECTS

http://designprinciplesandpractices.com/

First published in 2013 in Champaign, Illinois, USA

by Common Ground Publishing

University of Illinois Research Park

2001 South First St, Suite 202

Champaign, IL 61820 USA

www.CommonGroundPublishing.com

ISSN: $2325-1379$

(C) 2013 (individual papers), the author(s)

(C) 2013 (selection and editorial matter) Common Ground

All rights reserved. Apart from fair dealing for the purposes of study, research, criticism or review as permitted under the applicable copyright legislation, no part of this work may be reproduced by any process without written permission from the publisher. For permissions and other inquiries, please contact <cg-support@commongroundpublishing.com>.

The International Journal of Designed Objects is a peer-reviewed scholarly journal.

Typeset in CGScholar.

http://www.commongroundpublishing.com/software/ 


\title{
Thinking Outside the Square: Creating Value and Emotion in Ceramic Tiles through Design Led Innovation
}

\author{
Janet Coulter, University of Ulster, Co Antrim, UK \\ Dennis McKeag, University of Ulster, Co Antrim, UK
}

\begin{abstract}
This paper describes the design-led principles used to develop innovative, new products within the ceramic tile industry. It details how a traditional business model in a family-run company, was transformed into an 'innovation strategy' through design research. It describes how design principles from the textile industry transferred to ceramic tile design to develop innovative new products. The paper outlines the significance of creating value and emotion in ceramic tiles through aesthetics pertinent to shape, form, colour, pattern and crucially tactility. Two case studies demonstrated these strategies, which included attaching 'emotional value' to products, and allowed the Company to use the outcomes of the research to expand their product portfolio and achieve greater penetration into existing markets and gain access to new markets.
\end{abstract}

Keywords: Design-Led Innovation, Emotional Value, Creativity, Tactility, Surface Design, Product Innovation

\section{INTRODUCTION}

The Company partner referred to in this paper is a UK-based manufacturer, producing floor and wall tiles in ceramic, porcelain, marble, slate and granite. It employs production technologies that are traditional to this type of business and is the leading distributor of tile and marble surface products in Ireland. The key challenge facing the Company was how to increase growth and profitability in an environment where it was already the market leader and in the knowledge that growth and profitability had stalled in recent times. It was within this context that the authors carried out investigative research into the historical reasons for the Company's existing market-leading position in Ireland. This led to an analysis and evaluation of the business strategy. The objective was, through design research, to develop an innovation strategy that would provide continued growth and a sustainable business model. Two case studies illustrating how the research was implemented are outlined to help demonstrate how the goals were achieved.

\section{Rationale for the Research}

The Company is a tightly controlled, family-run business and although it was successful, it had not previously had to consider the reasons behind its success. The existing business model was based on low-cost, high-volume sales and it was becoming clear that these volumes would not exist in the future, largely due to the onset of the recession. As a consequence, the Company needed to find ways to continue to compete successfully, not only in traditional markets, but also to diversify into new markets. The Company realised that their existing business model was unsustainable and proactively sought collaboration with the University of Ulster in an attempt to diversify into new markets before the existing ones would go into meltdown. The ex-

The International Journal of Designed Objects

Volume 6, Issue 1, 2013, http://designprinciplesandpractices.com/, ISSN 2325-1379

(C) Common Ground, Janet Coulter, Dennis McKeag, All Rights Reserved, Permissions:

cg-support@commongroundpublishing.com 
isting model focused on sales, volume and margins driven by accountants and was no longer appropriate in the current economic climate. Further, the Company did not employ a designer and it was apparent that it did not understand the value of design or innovation.

Companies must innovate to sustain competitive advantage in an increasingly saturated, global market place. If managers cannot grasp the basics of innovation and design, then both will remain low on the company agenda. Studies carried out by Borja de Mozoto (1990) demonstrate that many managers have a poor understanding of how design works and how it impacts upon the performance results of a company. If companies face strong competition, then their operating environment will not allow for innovation and the creativity intrinsic to design (Bartlett and Goshal, 1995) and thus, some companies will remain cautious as innovation and change can increase risk in the short term and are likely to cause inefficiency and reduce productivity. Couple this with uncertain economic climates and the rapid advances in technology (Freeman, 1982) and a picture begins to emerge of the complexities that companies, such as our partner Company face in attempting to develop innovative, well-designed and desirable products, that meet the diverse needs of today's sophisticated and discerning customers.

Embracing a design strategy is not a simple solution and much debate still abounds regarding the 'meaning' and 'value' of design (Lorenz 1995). If design is valued in a company, it can become a key strategic asset in increasing competitiveness. Cooper and Press (2003) argue that as the level of understanding of design within a company increases, so also will its ability to create strategies for sustainable growth. Our partner Company had no resident designer and placed little value on design and it had become clear that its ad-hoc approach of 'design modification' would no longer suffice in the current economic climate. Hands (2009) contends that organisations can no longer afford to focus on low-cost products and must endeavour to produce value-rich products that are distinctive and appealing. He argues that design can contribute to competitive advantage and advises that companies need to integrate design at a strategic level. It was with these factors in mind that a business evaluation was undertaken and the framework for the research was set.

\section{Evaluation of the Business}

Analysis of companies who have a strong 'traditional' business, such as our partner Company, but who do not invest in innovation, demonstrates that they are more likely to fail. It has been shown that companies investing in design and employing innovation as key strategic weapon grow faster than competitors (Roy 1990). We evaluated the industrial competitiveness of the Company under the headings of Technology and New product programmes, as identified by (Pun, 2004).

\section{Technology}

Design has to operate within the constraints of existing technology and further investigation within the partner Company was aimed at identifying any existing technology that would bring them competitive advantage. Further, we concluded that the Company would need to recognise the importance of rationalising product development methodologies in order to improve efficiency and reduce prime costs and lead times to market. We recommended that virtual design sampling would be crucial to lowering production costs and that this could be achieved through CAD systems.

\section{New Product Programmes}

Research demonstrates that innovations that draw on technological capabilities that are readily accessible, are more likely to achieve sustainable competitive advantage (Ansoff, 1988; Miller, 1990). 
Although the Company did have own-brand products, these were perceived no better than their competitors' products at any price point. Our analysis on this basis, justified the prime objective of the research; to focus on design and product innovation and seek new opportunities to use existing technology to gain competitive advantage.

Our early evaluation concluded that an innovative approach to design would need to be embedded into the Company and become a key driver in it business. We presented a number of approaches to the Company, outlining how this could be explored using investigative research to determine if design could be a driver for reducing costs and bringing added value to existing products. The Company was clearly traditional in its approach to strategic planning and this was no longer yielding results in terms of growth. With an uncertain global environment, we advised that the Company would need to invest strategically in design-research and innovation, which could build perceived and actual new value into their products. This meant moving away from strategic planning and towards strategic innovation, as described in the Johnston et al. (2003) model; building a 'discovery team' to explore the future of a company and formulating a discovery process which would direct the Company to a new and innovative future. The discovery process differs significantly from the traditional planning process that the Company adhered to. The contrast between the two styles of planning is summarised by Johnston et al. (2003) in figure 1.

\begin{tabular}{|l|l|l|}
\hline & Strategic Planning & Strategy Innovation \\
\hline Process & Analytical/Quantitative & Creative \\
\hline Based on & Current Business Model & New Business Model \\
\hline Goal & Extend current Value & Create New value \\
\hline Focus & Company centric & Customer Centric \\
\hline Assumes & Future similar to the present & Dynamic Future \\
\hline Principles & Abide by rules/traditions & Break the rules \\
\hline
\end{tabular}

Figure 1: Source: Johnston et al. (2003)

\section{Recommendations from the Evaluation}

Prior to our research, the Company's ad hoc, incremental approach to innovation had achieved limited success. We recommended embedding a design champion who could build an innovation team and adopt a 'cross-pollinator role' (Kelley, 2004); a person with a different skill set to that which currently existed in the Company and who would be able to introduce new ideas and contribute new processes. We suggested that a textile designer would have the best skillset to bring hybrid ideas and techniques and transfer creative approaches from the textiles industry to the tile industry. This would bring a sense of rhythm, scale, repeat pattern and a fresh perspective on colour to the product range, with highly innovative and unexpected outcomes. Further, a textiles designer would have an understanding of fashion and lifestyle trends and be able to experiment and develop hybrid processes and deliver new outcomes that would offer appealing solutions to the Company's existing customers and to a potential new customer base. We concluded that a resident designer could build an innovation team within the Company, to create a 'greenhouse' where the cross-pollination and fertilisation of new ideas could take place, embedding strategic innovation based on the 'discovery team' model (Johnston et al. 2003). Textiles designers are highly skilled in understanding tactility in materials and appreciating how products need to embrace aesthetic functionality. They understand working to tight deadlines and the importance of achieving market presence early in any new cycle and the need 
to design to achieve profit margins at a given price point. We also suggested that a textile designer would understand the importance of psychological function that the products would need to relate to peoples perception of values. People interact with products in a physical and personal way, so physiological functions such as tactile feedback and perception are equally important. Textiles designers are very aware of the need to embrace social and ideological function as appropriate. Crucially, we believed that these skills would allow the Company to build 'emotional value' into their products.

\section{Creating Value through Emotional Attachment}

Cacioppo et al (2001) suggest that emotions provide meaning to everyday existence and that they give valuation to life and property. Verganti (2009) notes that design-driven innovation demonstrates how companies can successfully achieve radical innovations of 'meanings'. He contends that consumers do not buy products, rather they buy 'meanings', and that people use products for emotional and psychological reasons and not just utilitarian reasons. Companies therefore need to look beyond performance and functionality in products to understand the meanings that users attach to them. They must realise that customer preferences for both the rational and emotional aspects of a product can affect buying decisions. Further, they need to consider the potential that embedding emotional value into the products has to satisfy customers' desires. When a product can stimulate emotion in customers, it becomes appealing and has added value. Boatwright and Cagan (2010) suggest that customers will "richly pay" for products that offer emotional fulfilment. Research shows that products that have perceived emotional value outperform other products with the same functionality, even in a period of recession. This notion was particularly attractive to our partner Company which had identified that the high-volume, low-cost of sales that it had traditionally enjoyed were falling and a new strategy would be needed to address this. We advised the Company that if emotional values could be attached to its products, then this could provide differential and competitive advantage over competitors' products that have similar technical properties. The aim of our research was to investigate if textile-inspired methods of creating emotional responses and values in product ranges could increase consumers' likelihood of purchasing them. Hirschman \& Holbrook (1982) contend, "Where emotions can be induced through products, then the consumer will have enhanced enjoyment in buying, and owning them". Our goal was to undertake radical innovation within the Company and build emotional value into the products to reach new markets and new customers.

Valik (2006) notes that some companies employ designers to create stronger, emotional connections with their customers and suggests that a key way to achieve this is to emphasise the characteristics of materials, surface structure and the sense of touch. McDonagh (2004) concurs and stresses the importance of customer perception in touching products, contending that the emotional effect from a tactile experience is stronger than from a visual experience. These viewpoints justified our recommendations to the Company that a textile designer, would offer the appropriate skillset to attach meanings to products and deliver emotional value that customers could connect with.

\section{Research Framework}

There are numerous research studies that attempt to quantify how emotional value is attached to products; however it is our opinion that many of these studies tend to be objectivist, overemphasising the power of design to actually create emotion. Our view is that design is not so much responsible for generating emotion, but rather for encouraging it. Parasuraman (1997) argues that with so many variables, no single method of measurement can define what constitutes value. With no definitive methodology for measuring the highly abstract concept of emotional value, we used a more ethnographic, organic approach to conduct our investigations. We did 
however, draw on one framework presented by Desmet \& Hekkart (2007) as a useful reference when considering how to frame our research questions in relation to emotional value. This framework contends that the advantage of emotional value of a product is associated with the affective experiences of the user who interacts with it and that the experiences happen on three levels: (i) aesthetically pleasing, in a sensory capacity, (ii) meaning, relative to a viewer's character, and (iii) emotion, invoked by strong feelings such as desire. Desmet and Hekkert (2007) further note that the nature of affective experiences is dependent on setting or environment. These perceptions are influenced by lifestyle trends and fashions and may be subject to regional or geographical differences.

The authors posed the following questions: could the skill set of a textile designer-

- be used to enhance the sensory capacity of the product, using surface interest, texture and tactility?

- persuade customers, through design, to think of tiles as a lifestyle trend, which needs to be replaced as fashion lifecycles change?

- take advantage of regional, geographical and environmental factors to develop new design solutions?

To address these questions we tasked our textiles designer to research and experiment with cross-pollinating ideas, techniques and approaches from textiles and apply them to tile design. The designer was encouraged to actively consider building emotional value during the design process. The responses to the ideas were tested through a number of work-in-progress presentations. These included cross-departmental R\&D meetings within the Company, setting up innovation showcases in the Company showrooms using 'show and tell' storyboards to explain the innovation to customers. The customers were invited to give their views on the new products. The new design ideas were also taken to international trade fairs to test the emotional response of the marketplace.

Esslinger (2009) argues that innovation must put ideas into the context of a meaningful process to be of any value. We considered issues of value in the wider context of the Company's image, as well as their individual products. We used the VIPP model (Trueman, 1998), (figure 2) to map the outcomes of our research and articulate how the value of the Company image, new products and processes was achieved in relation to tactility, life cycles and demographics. 


\section{VIPP Typology of Design Value in Product Development}

\begin{tabular}{|l|l|l|}
\hline Design Strategy & \multicolumn{1}{|c|}{ Design Attributes } & \multicolumn{1}{c|}{ Company Goals } \\
\hline Value & $\begin{array}{l}\text { Product Styling } \\
\text { Aesthetics } \\
\text { Quality } \\
\text { Standards } \\
\text { Added Value }\end{array}$ & $\begin{array}{l}\text { To add value for consumer and } \\
\text { enhance Company reputation }\end{array}$ \\
\hline Image & $\begin{array}{l}\text { Product differentiation } \\
\text { Product diversification } \\
\text { Product identity } \\
\text { Brand creation }\end{array}$ & Company image and strategy \\
\hline Process & $\begin{array}{l}\text { Generate new ideas } \\
\text { Idea communication } \\
\text { Interpret ideas } \\
\text { Integrate ideas } \\
\text { Promote products }\end{array}$ & $\begin{array}{l}\text { Culture for new ideas. Creativity } \\
\text { and innovation }\end{array}$ \\
\hline Production & $\begin{array}{l}\text { Reduce complexity } \\
\text { Use new technology and materials } \\
\text { Reduce production time }\end{array}$ & $\begin{array}{l}\text { Improvement and reduce time to } \\
\text { market }\end{array}$ \\
\hline
\end{tabular}

Figure 2: Source: Trueman 1998

\section{Value}

Value is associated with price in relation to benefit (actual or perceived). Utilitarian products, for example traditional white tiles, tend to be price sensitive. In a product such as tiles, where the visual aesthetics and surface tactility largely determine the real and perceived benefit, design clearly determines the value the customer will place on the product. Using a textile design approach, we were able to successfully embed attributes into the product that provided the customer with expected and unexpected benefits as an excitement feature. Emotional value was built into the tiles as a result of extensive experimentation with a range of hybrid textile techniques, to enhance visual perception and tactility. These included screen-printing on to tiles, experimenting with flocking processes, printing tiles digitally with UV hard surface printers, laser etching, glass fusion and developing unique 'groove and glaze' techniques. The latter technique involved using the existing technology of water jet cutters and scoring into the tiles to various depths and filling the resultant groove with coloured glazes and re-firing. This process was perfected over a number of months and was unique, as the coloured groove remained unaffected by grouting. This resulted in a two-colour tile, incorporating both matt and gloss surfaces. Creating sensory capacity and achieving tactile surfaces on the new product ranges resulted in a greater connection with customers. The products were well received by customers and the impact of this was realised in new sales and reaching new markets.

\section{Image}

The development of the 'Cathedral' and 'Logos \& Legends' ranges which are described in the case studies, brought product diversification, differentiation and created a new brand, which enhanced the Company's image. The Company's reputation for innovative design developed and as a direct result, it secured new business in the heritage restoration sector. 'Logos \& Le- 
gends' provided an opportunity to take advantage of the emotional value that customers place on demographics, contexts and environments. A local theme of "Our Wee Belfast Boy", which had great emotional value in the region, was selected to inspire a large-scale panel suitable for public display. The concept behind 'Logos \& Legends' is that value and emotional attachment can be developed through themes and products tailored to a range of contexts and environments globally. What is important in one setting may not be perceived as having value in another setting and as such, bespoke products can be created, which have emotional value and bring opportunities to develop differentiated products with USP.

\section{Process}

The new product ranges created a new culture for ideas and innovation within the Company. They were tested in showrooms and at trade fairs and the products were promoted as having a trend-based lifecycle, encouraging customers to consider changing their tiles as interior fashions change. Additionally, trends in city living and loft style apartments allowed opportunities for new ranges of bespoke, large-scale products to fit in and around entire areas in apartments, encouraging customers to 'think outside the square.'

\section{Production}

Knowledge of textiles was crucial in identifying and bringing on board new production processes that contributed to the creation of innovative products and enhanced the image of the Company in terms of innovation. Its focus shifted from being tile manufacturers to becoming providers of aesthetically pleasing, durable surfaces. The case studies provide two examples of how this was achieved. Research sought new ways whereby existing and new production technology and materials could be used to broaden the product portfolio and provide customers and clients with new, exciting and innovative solutions. Design development techniques were reduced in complexity by shifting laborious hand-cut, sampling techniques to CAD design, allowing for virtual sampling and thus reducing time and cost of production.

\section{Case Study 1: The Cathedral Range}

Whilst renovations were being carried out at a local Church, in Belfast, a partially intact tiled floor, which had suffered damage was discovered beneath a covering of concrete. The Company was contacted by the church to ascertain if it would be possible to restore the floor to its original glory. The original tiles were handmade, and the pattern was intricate. Company staff assessed the damage and suggested replicating the design in CAD, and through CADCAM linking the computer to a water-jet cutter to produce the appropriate shapes of the original tiles from colour-matched tiles, produced using modern techniques (Figure 3).

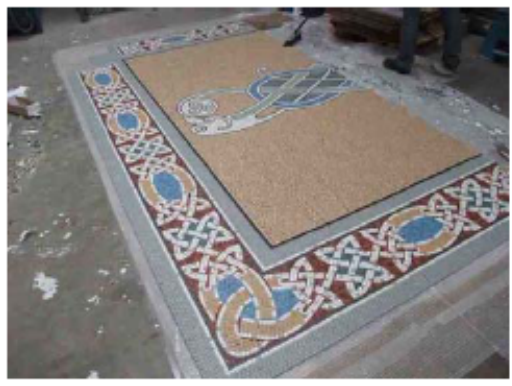

Figure 3

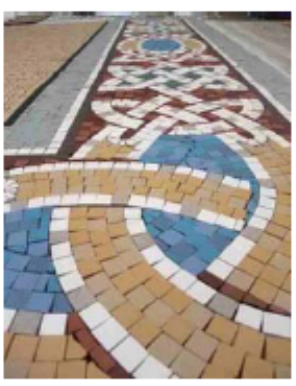

Figure 4

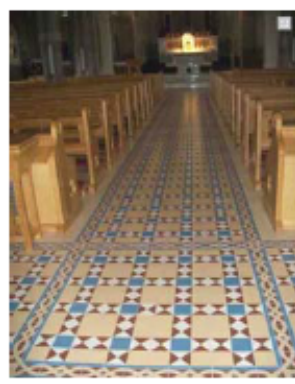

Figure 5 
The tiles were then "distressed" in a deburring machine to ensure that the newly laid floor would match the remains of the original floor in terms of pattern, colour and texture (Figure 4). The solution was completed to cost, time, budget and above all, specification. The design team was then able to use the colours, motifs and theme of the restored mosaic floor to develop a complementary range of tiles for use throughout the church (Figure 5). During this work the Company saw the opportunity to develop a new range of tiling solutions based on 'period' design, which it now refers to as its "Cathedral Range." ${ }^{1}$ In doing so it responded to the opportunity of developing traditional, heritage-based products with emotional value within a given context.

\section{Case Study 2: "Logos and Legends"}

Within the framework of the research, the new design team investigated the capability of the Company's existing manufacturing technology, with the objective of using any untapped capability to enhance its product portfolio. The design team experimented with water jet cutting, setting the jet parameters to leave a surface indentation of different depths, rather than cutting through the tiles. Further experimentation of the technique led to the design of "celebrity" murals in tile. This received very positive customer feedback and the design team saw a market opportunity to design a range of unique, large-scale panels, with end uses suited to public and corporate buildings. These were marketed under the heading "Logos and Legends", 2 the principle being that customers from different regions can be provided with surface decoration, featuring celebrity or meaningful icons that meet their needs and are important to them in their own context. The Company was able to harness the concept of 'meanings' and 'emotional value', to develop this product. The emotional attachment, coupled with the ability to customise meanings to suit a wide range of demographics gave the product a unique selling point (USP) and global appeal. Designs can be developed and customised online, thus opening up new global markets and new ways of selling.

\section{Conclusions}

Within two years, knowledge and understanding of design and innovation had been embedded within the Company. Hybrid skills of a textiles designer successfully enhanced the sensory capacity of the products using surface interest, texture and tactility through a range of processes. As the new product innovation developed, customers were persuaded to think of tiles as a lifestyle trend, rather than tiles for life. This was largely due to the presentation of the new products at international fairs. Results were measured in interest registered and new sales achieved. Taking advantage of regional, geographical and environmental factors such as the wealth of churches within Ireland and the regional interest in Irish Heroes, allowed the Company to exploit and attach emotional value to their product ranges and achieve commercial success.

Analyses of the research were acted upon and the authors mentored the Company throughout the transformation process and it now has the confidence and capability to proactively develop new product lines, undertake radical new product innovation and offer bespoke, innovative and creative surface solutions beyond the scope of the overwhelming majority of architects and interior designers. The 'Cathedral Range' and the 'Logos and Legends' collections have proven very successful and the Company has a clear understanding of the value of design and of the significance of attaching meanings and emotions to its products to enable it to connect more effectively with existing and new customers. The R\&D department continues to bring diverse

\footnotetext{
${ }^{1}$ http://www.armatile.com/pdf/ChurchBrochure.pdf

${ }^{2}$ Legends \& Logos: mhttp://www.armatile.com/categories/760/4/logos-and legends.aspx?expandable=4
} 
and hybrid skills and new ideas such as incorporating glass fusion. The impact of this has meant that the Company has been able to harness its existing technology for use in more innovative, design-led projects and has used CAD to enhance design and reduce labour-intensive sampling costs. Market share has increased, as has growth and profitability and the Company now has a sustainable business model based on design-led creativity and innovation. 


\section{REFERENCES}

Ansoff, I., 1988. New Corporate Strategy; John Wiley \& Sons Australia, Limited

Bartlett, C.A., Ghoshal, S., 1995. "Rebuilding behavioural content: turn process reengineering into people rejuvenation.” Sloan Management Review

Boatwright, P., Cagan J., 2010. Built to Love: Creating Products That Captivate Customers. Berrett-Koehler Publishers

Borja de Mozoto, B., 1990. Design as a strategic management tool in Oakley, M (ed.) Design Management: A Handbook of issues and methods. Basil Blackwell, Oxford

Buchanan, R., 1985. Declaration by design. Design Issues, 2(1), 4-22

Cooper, R., Press, M., 2003. The Design Agenda; A Guide to Successful Design Management. John Wiley and Sons

Cacioppo, J., T., Berntson, G.G., Larsen, J.T., Poehlmann, K.M., Ito, T.A., 2001. The psychophysiology of emotion. In M. Lewis \& J.M. Haviland-Jones (Eds.), Handbook of Emotions (2 $\left.{ }^{\text {nd }} e d.\right)$ (pp. 173-191). New York: The Guilford Press

Desmet, P. M. A., Hekkert, P., 2007. Framework of product experience. International Journal of Design, 1(1), 57-66

Esslinger, H., 2009. A Fine Line: How Design Strategies Are Shaping the Future of Business. John Wiley \& Sons Inc.

Freeman, C., 1982. The Economics of Industrial Innovation, $2^{\text {nd }}$ edition, London

Hands, D., 2009. Vision and Values in Design Management. AVA Academia

Hirschman, E.C., Holbrook, M.B., 1982. Hedonic consumption: Emerging concepts, methods and propositions. Journal of Marketing, 46, 92-101

Johnston, R. E., 2003. The power of Strategy Innovation; A new way of linking creativity and strategic planning to discover great business opportunities. Amacom

Kelley, T. with Littman, J., 2004. The Ten Faces of Innovation; Strategies for heightening Creativity. Profile Books

Lornez, C., 1995. Harnessing design as a strategic recourse. Long Range Planning, Vol. 27, No. 5, pp. 73, 1995

Miller, D., The Icarus paradox: How exceptional companies bring about their own downfall. New York: Harper Business. 1990

McDonagh, D., Hekkert, P, Erp, J van \& Gyi, D (Ed.), Design and emotion: the experience of everyday things. (pp. 228-232). London: Taylor \& Francis; 2002

Pun, K. F. et. al. 2004. Determinants of manufacturing, strategy formulation: A longitudinal Study in Hong Kong Technovation: International Journal of Technical Innovation and Entrepreneurship, 24

Roy, R., Potter, S., 1990. Design and the Economy. The Design Council

Trueman, M., 1988. Managing innovation by design-how a new design typology may facilitate the product development process in industrial companies and provide a competitive advantage. European Journal of Innovation Management, Vol. 1 Is: 1, pp. 44-56

Valik, T., Kourennayia, D., 2006. Exploring and teaching tactility in design: Working paper, Nordecode Oslo, May 2006 http://nordcode.tkk.filoslopapers/Tom_Vsavik.pdf

Verganti, R., 2009. Design Driven Innovation. Harvard Business School Corporation

Innovation Measurement: Tracking the State of Innovation in the American Economy; A Report to the Secretary of Commerce by The Advisory Committee on Measuring Innovation in the $21^{\text {st }}$ Century Economy; January 2008; http://www.innovationmetrics.gov/-accessed May 2011

Fig 1: Discovery Process Model; Johnston et al. 2003

Fig 2: VIPP Model; Trueman 1988

Fig 3: St Colmcilles Church, in Belfast, Restoration image 1 
Fig 4: St Colmcilles Church, in Belfast, Restoration image 2

Fig 5: St Colmcilles Church, in Belfast, Restoration image 3

\section{ABOUT THE AUTHORS}

Janet Coulter: Janet Coulter is a Senior Lecturer at the University of Ulster and specialises in innovative design solutions for the wider Textiles \& Fashion industry. Ms. Coulter is from an industrial background and spent the early part of her career working in Paris, as an International Trend and Design Researcher, in the area of future intelligence and creative design tools for the global market. She went on to spend time with a Design House in London, before returning to Northern Ireland to take up a position as a design manager in a manufacturing based company, where she managed design portfolios for a number of large UK based retailers and corporate organisations. Ms. Coulter joined the University of Ulster in 1999, to lecture in Fashion and Textiles Design. Her research has been based around product innovation, most recently, specialising in enhanced design and shaping protective body armour for females. She also develops design solutions for protection in sportswear for contact sports and has a sound of knowledge in performance and technical textiles. Ms. Coulter has successfully led a number of technology transfer programmes over recent years within these areas. She also holds the position of Faculty co-ordinator for Academic Enterprise, within the Faculty of Art, Design and The Built Environment at University of Ulster, with a remit for forging and developing industrial collaborations between the Faculty and the creative industries.

Dennis McKeag: Professor McKeag specialises in innovation and is the leading UK academic recipient of Technology Transfer Grants. Professor McKeag works with large and small companies in product and process innovation. The early part of his career was spent as a research and development engineer in the aerospace industry. Thereafter he moved to The University of Limerick whre he was responsible for BA/BSc Industrial Design programmes and taught Engineering Science. He moved to Engineering department of The University of Ulster assuming responsibility for design, and after 7 years was transferred to The Faculty of Art and Design, and helped the associated research Institute achieve grade 5 status in the RAE and number 1 status in the UK in their category. After 15 years he returned to Engineering and for the past five years has been developing industry led technology transfer programmes. He has won and been associated with a number of major awards including Best Managed Large Company in Britain Award in 1995 with Takata Corporation, National Innovation Award for Large Companies in association with RFD in 1997, and was awarded the Business Fellowship in 2003. 

The International Journal of Designed Objects is one of six thematically focused journals in the family of journals that support the Design Principles and Practices knowledge community-its journals, book series, conference and online community. It is a section of Design Principles and Practices: An International Journal.

AThe journal examines the nature and form of the objects of design, including industrial design, fashion, interior design, and other design practices.

As well as papers of a traditional scholarly type, this journal invites presentations of practice-including documentation of designed objects together with exegeses analyzing design purposes, purposes and effects.

The International Journal of Designed Objects is a peerreviewed scholarly journal.

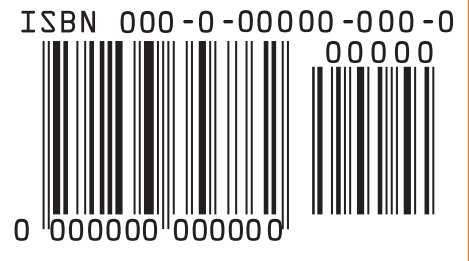

